\title{
Imagined communities and practiced geopolitics
}

\author{
HERMAN VAN DER WUSTEN ${ }^{1}$
}

\begin{abstract}
Political geographers have done a lot of work on both 'nationalism' and 'geopolitics' but they have by no means been the only users of these terms. Based on the massive data-set collected by Google's book digitization program the paper first draws a quick picture of the spread of these terms in different languages since 1900. It then provides some analysis of the substance of these terms as used in the social science literature and in political geography in particular. In a next section the current Ukrainian conflict formation is introduced as a case to illustrate the usefulness of these concepts. Internal Ukrainian relations are taken into account with respect to nationalist sentiment as well as geopolitical practice as well as the contrary geopolitical visions of the major external actors involved. Some suggestions on the shifting significance of nationalism and geopolitics are finally made as a consequence of changed circumstances resulting from globalization and the concomitant weakening of the national state as the firm foundation of the political order.
\end{abstract}

Keywords: nationalism, geopolitics, imagined community, Ukraine

\section{Introduction}

Political geographers have spent a lot of time with nationalism and geopolitics. In this paper I return to that legacy and confront it with the ongoing conflict in Ukraine. Obviously, the views on this current episode have to be provisional as we deal with a highly volatile situation. I look at nationalism as the manifestation of a shared belief in commonality - past, present and future - among large groups of people, far too large to get to know each other personally. As far as geopolitics is concerned I concentrate on geopolitics as a practice by power holders to engage in policies inspired by spatial configurations that should either be maintained or altered.

Political geographers have by no means been the sole interested parties in nationalism and geopolitics. Historians, political scientists, sociologists and others were also engaged in their study. This applies to both words although geographers played a relatively prominent role in the case of geopolitics. We can see the general use frequencies of the words 'nationalism' and 'geopolitics' in the English language literature since 1900 in some graphs derived from Google's set of 5 million digitized books by way of the $\mathrm{N}$-gram viewer (https://books.google.com/ngrams). The curves roughly show the number of times the words have been used per year corrected for the number of books digitized, thus correcting for the continuous increase in the published literature. The curves in fact show scores as moving averages thus suppressing outliers.

There are some variations in their precise shapes in this and subsequent figures depending on spelling (capitals or not) and adjective forms added (yes or no), but the major features remain the same. The curve for 'geopolitics' is shown twice to underline the differences between the frequencies in the use of both words (Figure 1a) and to provide a more detailed impression of the curve for 'geopolitics' (Figure 1b).

The literature on nationalism is much larger than that on geopolitics as suggested by the scores for the culminating points: top rat-

\footnotetext{
${ }^{1}$ Department of Geography, Planning \& International Development Studies, University of Amsterdam, 1001 NC Amsterdam, Netherlands PB 15629. E-mail: h.h.vanderwusten@uva.nl
} 


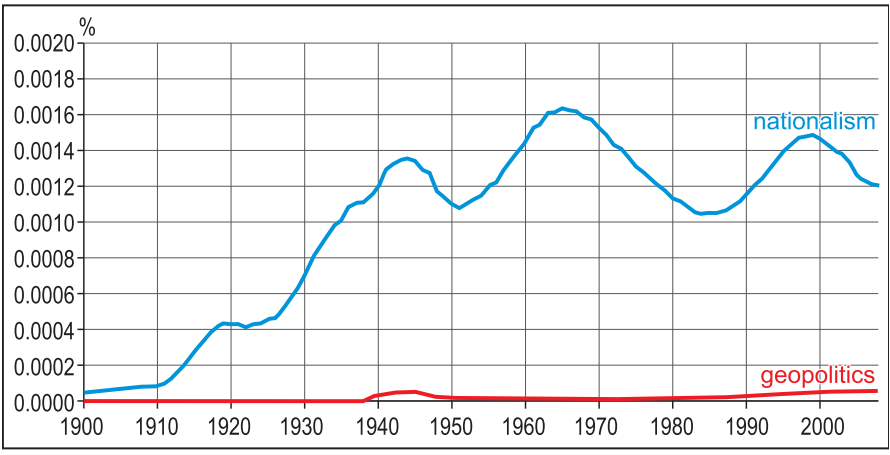

Fig. 1a. N-gram 'nationalism' and 'geopolitics' 1900-2008 (English corpus). Source: https://books.google.com/ngrams/info

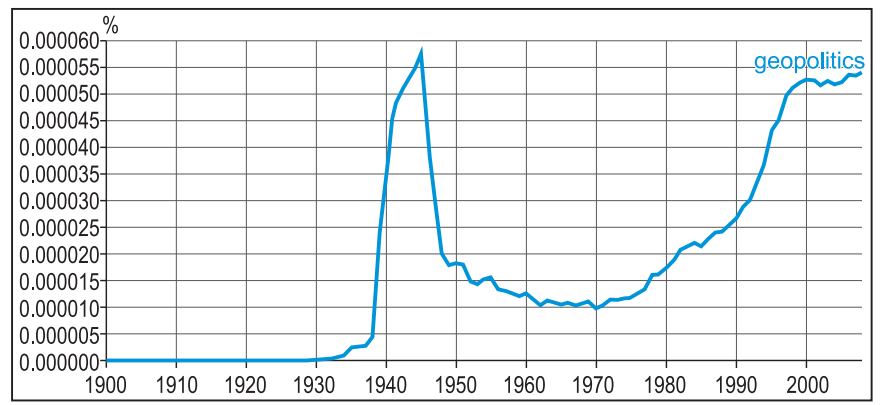

Fig. 1b. N-gram 'geopolitics' 1900-2008 (English corpus). Source: https://books.google.com/ngrams/info ments of nazism that sharply diminishes as the war ends and another upsurge of the use of this word in a completely altered context from the 1970s. The more recent growth is still unfinished but since about 2000 trailing at a high level that is less easy to interpret.

\section{Nationalism}

For my recap on nationalism I use two authors: Benedict ANDERSON who in fact introduced the notion of imagined communities as the basis for nationalism and Robert J. Kaiser. Anderson first appeared as the wave of studies reflecting decolonization had come to an end (ANDERSON, B. 1983). KaISER published his 'Geography of nationalism in Russia and the USSR' three years after the collapse of the Soviet Union (KaISER,

ings are more than 30 times higher for nationalism (it is rather improbable that the word nationalism is used much more frequently in books on nationalism than geopolitics in books on that particular subject). But I am more intrigued by the shape of the curves. Nationalism has three culminating points in 1943, 1965 and 1998. They apparently reflect current affairs more than internal academic developments, notably: nazi inspired expansionist imperialism and World War II in 1943, the massive process of decolonialisation in 1965 , and finally the upsurge of ethno-regionalism all across Europe and particularly the demise of the USSR and Yugoslavia in the 1990s. Geopolitics has a sharp culminating point in 1944 and a provisional second high point in 2008, the last year with data. It suggests yet another state of intensified reflection on the presumed contributors or accompani-
R.J.1994). He took the major theoretical contributions of the preceding years by e.g. Karl W. Deutsch (1953), Walker Connor (1978), Anthony D. Sмiтн (1986), Miroslav Hroch (1985) and Ernest Gellner (1983) and also ANDERson (1983) into account.

Nations, so ANDERSON, are necessarily imagined communities; they are much too large to allow mutual personal acquaintance for all individuals supposedly belonging to the community. The nation is necessarily imaginary but the image may be strong. ANDERSON considers the printing press and territorial government to be the major initial foundations of the emergence of the national idea. The nation is a fruit of the late $18^{\text {th }}$ century. The press stimulates the standardisation of a written language, provides a more or less uniform perspective on the world and introduces its readership to a nearly simultane- 
ous, frequently repeated example of that perspective. Territorial government implies the demarcation of administrative boundaries and thereby determines the spatial range of the use of administrative languages plus the trajectories of the professional careers of those in state employment. The resulting nations are imagined maximally autonomous. This idea has become the central vehicle for nationalist ideologies and social movements in the past two centuries.

Obviously, media and governing had already strongly changed by 1983 and have transformed since by the impact of globalization. ANDERson himself has taken this into account by introducing the notion of long distance nationalism (ANDERson, B. 1992). It refers to instances of migrant communities that despite their stable new residence quite far away from their places of origin maintain intimate links with their homeland over the longer term. They occasionally engage in extremism if their original imagined community is deemed in danger. He considers this as one consequence of globalisation enabling such contacts and the practicing of ideas uninhibited by constraints in the real old country. While this may be true the effects of globalization should not be overestimated. Irish $19^{\text {th }}$ century nationalism was already nurtured to a major extent by Irish Americans (VAn der Wusten, H. 1980).

Robert J. KaISER in his turn was mainly concerned with the USSR including Russia. But he started with a theoretical chapter on the meaning of homeland in the study of nationalism that draws the linkages between nation/ nationalism and territory. Nationalism, once activated as an ideology and a movement, pursues the control of a homeland. Since the Bolchevik revolution KAISER found rivalry between a set of emerging nationalisms connected to the territories of the administrative divisions of the USSR with governments that had at least some socio-cultural competences and an overarching Soviet community not to be called a nation for ideological reasons but very similar in kind. In the end the lower level nationalisms turned out to be more suc- cessful and caused the demise of the entire structure. The creation and acceptance of ethnic elites in the different parts of the federal structures and their mobilizing capacities based on growing levels of modernization doomed the entire edifice.

A major part of the explanation is the wrong diagnosis and prognosis from Lenin onwards that the diverse national feelings in the USSR could and should be accommodated in the constitutional structure of the state by means of a notional federalism. These national feelings would be undermined and wither away as a result of the modernization of Soviet society in its communist mould directed by the party. In actual fact the privileges provided by the structure of government following the (con)federal constitution to the various majority populations in the different administrative entities created the opportunities for multiple nation-building processes that overturned the system by ruining the unity of the party. It was in many respects the replay of the demise of the Austro-Hungarian Empire by the loss of the civil and military imperial organs against the various nationalisms in the regions (see Joseph Rотн's Radetzkymarsch [1932] for a literary representation of the process). It was the example that Lenin was trying to avoid at all cost, in vain.

Within all the administrative divisions there were ethnic minority populations. The proportions of Russians in particular were often significant. Russians of course held special positions as members of the principal nationality of the USSR and in many cases the professional elites in the various regions. It could have been an option for many people with a different ethnic background to 'russify' but particularly after 1945 this trajectory was taken by relatively few people. Although it was by then encouraged by the centre and proficiency in Russian was very important for social improvement, people mostly learned Russian as a second language only and did not opt for full 'russification'. While the idea of one Soviet people became increasingly ephemeral and most people looked to 
their various national homelands as their primary place of belonging, Russians in particular could well hesitate between a national Russian homeland or the entire USSR as their national homeland.

Since 1991, on the former territory of the USSR, the territorial expression of the new state system, the very definition of the homeland in nationalist parlance, has repeatedly been strongly contested. In KAISER'S analysis of the last stages of the USSR and its disappearance, it looked too much as if the physical containers of the different nationalities had all been sufficiently strongly constructed for the homelands to emerge and provide stable residences into the future. Ukraine is the most recent dramatic counterexample.

\section{Geopolitics}

Geographers used to look at geopolitics as their own renegade and more recently perhaps more as their prodigal son but this has always been wrong. From the very beginning it was a concept also nurtured outside geography. KJELLÉN, its main inventor was a jurist with political science inclinations. He first introduced the word geopolitics in a paper in Swedish published in 1899, its most elaborate and famous treatment is in 1917 in German (Holdar, S. 1994; KJellén, R. 1917). We can again follow the evolution of the use of the concept, now in different languages, via Ngrams from the Google dataset (Figure 2).

Obviously, not quite correctly we read the corpora of books in different languages here

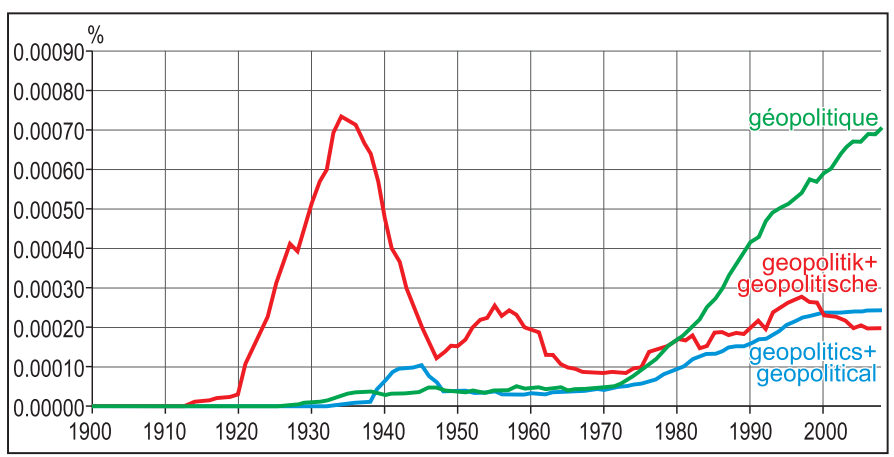

as a reflection of the interests in the predominant countries using that language. It is possible to make a distinction between American and British English but it does not show important differences in the nature of the curves so we consider the curve for English language books as a reflection of the US and the UK together.

The curves in Figure 2 show that the word geopolitics first took off in Germany, particularly after the end of World War I and reached its highest rating in 1934. The use frequency then fell off sharply just after Hitler had come to power in Germany. Despite clear signs of collaboration with the nazis well into the new war from the side of the protagonists of geopolitics, the significance of geopolitics fell off sharply within Germany until the end of the war. At the same time World War II unchained a geopolitical literature in the Anglo-Saxon countries mostly in response to German geopolitics and very often highly critical vastly overestimating its significance in the German war effort. Compared to the German use frequencies it remained small. From the 1970s there was a resurgence of interest in geopolitics apparently starting in France and growing at a relatively steep rate. France has remained the most sustained growth area for geopolitical discourse until the end of the period (Figure 3).

In the 1980s first in Chinese and then in Russian a steep growth curve of the use of the term geopolitics can be discerned. For comparative purposes the English language curve has again been added. It is here again pictured on a different scale. While both dominating states in these language groups (China and the USSR/Russian Federation) found themselves in much altered international positions during these years they

Fig. 2. N-grams Geopolitics German, English French 1900-2008.

Source: https://books.google.com/ ngrams/info 


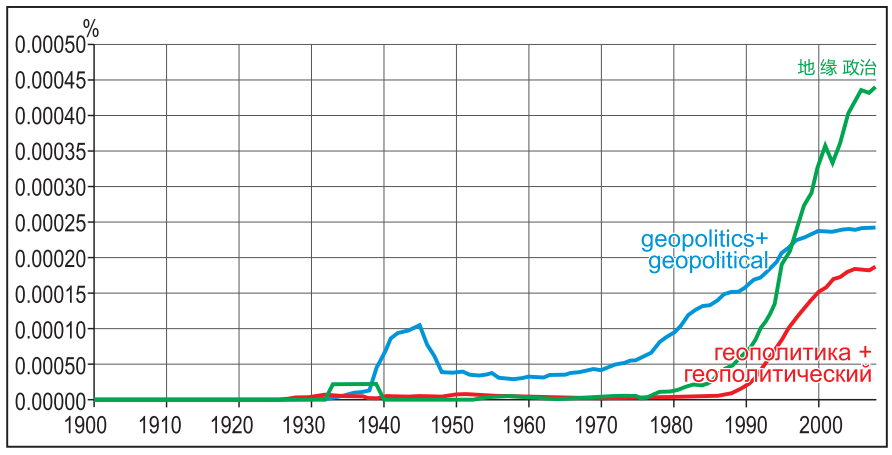

Fig. 3. N-grams geopolitics Chinese, Russian, English 1900-2008. Source: https://books.google.com/ngrams/info

quickly adapted to the renewed popularity of geopolitics in the West but presumably used it for their own purposes. The particularly steep Chinese growth rate is intriguing. I will briefly return to the Russian curve in the context of the Ukrainian case.

One way to quickly summarize the temporal trend in the shifting central interests of geopolitics may be gleaned from the perusal of works from different periods. I use three sets of authors: first MACKINDER and Haushofer, subsequently DiJKInK and PAAsi and finally O'Loughlin, Toal and Kolossov. One important differentiating point is how geopolitics connects with nationalism in these works from the pre-1945 period, the 1990s and the current era.

Shortly after KJELLÉn had put the term geopolitics to use in 1899, MACKINDER painted the first version of his celebrated thesis on the increasing importance of the Eurasian core as the pivot of the world (MACKINDER, H.J. 1904). Its importance was increasing, he said, because of the shifting balance in transport opportunities across sea lanes and train tracks with the tracks getting the upper hand. His views became a source of inspiration for Karl Haushofer who used the term geopolitics for his further deliberations on the subject. Haushofer dealt with the macro-regional distribution of power and influence in the world, with the position of Japan and the evolution of policies regarding the Pacific and most of all with the reparation of
Germany's position as a great power after the Versailles Treaty (Haushofer, K. et al. 1928).

While Mackinder was undoubtedly primarily concerned with the position of Britain in the new global spatial constellation that he saw coming, Haushofer's perspective was primarily drawn to the issue of Germany's fate after a new global spatial constellation had arisen as the outcome of World War I. In MACKINDER's view Britain was the British nation (with a certain acceptance of internal differentiation in English, Scottish, Welsh and Irish) and a reserved huge outdoor area parcelled across the world, altogether the British empire. This was the great power and the question was how it could be preserved under the new circumstances. In Haushofer's view Germany, in Versailles, was bereft of a significant part of the homeland of the German nation and it did no longer play a role across the globe in territorial terms. It had lost its own outdoor area. It did no longer belong to the restricted club of great powers. These powers were the significant geopolitical actors and Germany's status as one of them should be restored.

In this perspective there is in the end no place for geopolitical actors outside these restricted few. Nationalism within the state central to the great power may be a source of inspiration for the great powers' geopolitics, in other cases nations may serve as stabilizers or contestants of existing state constructions but they do not play in the practiced geopolitics of these states as the conduct of great power politics lies ultimately in the hands of a restricted set of power holders and is largely constrained by a set of physical conditions.

Taking some leafs from the folder of critical geopolitics as developed by Agnew, O'Tuathail, Dalby and others (O'Tuathail, G. and Agnew, J. 1992, Dalby, S. and O’Tuathail, G. 1998), Dijkink and PaAsi 
have in the later 1990s indicated the way in which nationalism expressed in feelings of national identity on the one hand and geopolitical visions and practiced geopolitics on the other are co-constituted over time in a long process of shared experience. DIJKINK reconstructed the maps of pride and pain as he calls them for eight different countries (Dijkink, G.J.W. 1996), PaAsi considered the consequences of Finnish territorial loss for its geopolitical practice and national identity (PAAsI, A. 1996). State actors have here been deconstructed in a series of policy makers, their institutions and the fine grained enormous body of opinions that goes under the title of public opinion. It has been generally recognised that all sorts of representations held by these various actors result in visions and practices regarding territories. At the same time all these people supposedly share to some extent a sense of commonality that evolves in the imagined community which forms the mainstay of nationalism. This nationalism channels the visions, the visions enrich the commonality.

In the last couple of years O'Loughlin, Kolossov and ToAl have extensively studied a large number of territorial conflicts on the territory of the former USSR (O'LoughLIN, J., Kolossov, V. and Toal, G. 2011; O'Loughlin, J., Toal, G. and Chamberlain-Chenga, R. 2013; Toal, G. and O'Loughlin, J. 2013a,b). Ethno-national rivalries play out generally but there are other issues as well: religion, nostalgia of the Soviet past. A recurring feature in many of their surveys is the widespread positive memory of the Soviet era. A number of issues between conflicting parties have been frozen in a state of suspended conflict resolution. Despite the ethno-national identification of many of the issues and the main protagonists, massive mobilisation is generally low. The central Russian government acts as a kind of arbiter on its own territory and in the surrounding zones with the aim to remain the predominant and indispensible power. It results in semi-sovereign, feeble governing constructions that may nonetheless long survive. This form of negli- gent supremacy used to be called suzerainty in earlier great power days. Nationalism may be instrumentally called upon for a while but the ultimately relevant actor is the presumed great power brought to life by a small set of closely connected institutions (intelligence services, police, military) (O'Loughlin, J., Kolossov, V. and Toal, G. 2011).

In sum, practiced geopolitics has been the preserve of different actors over time. As geopolitics emerged it was mainly, sometimes exclusively considered the business of great powers. Within a great power nationalism was an important conditioning factor, but certainly not the only one. More recently, as nationalism had spread throughout the world resulting in the process of decolonisation, the potential power of imagined national communities was sharper realised.

There was a degree of recognition of all states as principally equal partners and a universal and intimate relation of imagined communities and practiced geopolitics was more or less assumed. Now, on the territory of the former USSR efforts are made to restore a spatial constellation of geopolitical relations very much like that within the great power constructions of the past. This is to repair 'the greatest geopolitical disaster of the $20^{\text {th }}$ century' as Putin has called it since 2005. For Russia to play its full role in the new league, the disaster damage has to be repaired and the old foe, the US and the new potential, the EU, kept at bay.

\section{Ukraine in light of imagined communities and practiced geopolitics}

The current Ukraine conflict formation was initiated when president Yanukovych abruptly suspended the final preparations for the signing of the EU-Ukraine Association agreement under Russian pressure. This was followed by mass protests at first limited to a central square in Kiev (Maidan) and a further series of dramatic episodes - a widening of the protests across the country, the flight of Yanukovych, the reincorporation of Crimea 
in the Russian federation, the attempts at revolt against 'Kiev' in East Ukraine notably Donetsk and Lukhansk, the Ukrainian military campaign against separatist territory and the different kinds of support from the side of Russia, the diplomatic effort and the monitoring by the OSCE.

A recent paper in this journal (KARÁCSONYI, D. et al. 2014, 99-134) has some very interesting maps (particularly 13,14) on the early part of the conflict. One astounding feature - astounding for the suggested initial density of these items - is the number of Lenin monuments destroyed between November 2013 and February 2014 in major parts of the country though less frequently in the West (where such monuments had already been removed in earlier years) and in the East where they apparently were left alone. Surprisingly, the map shows a number of such destructions in Crimea. In further comments based on the previous sections I will particularly focus on the apparent relevance and manifestation of Ukrainian nationalism in the ongoing conflict and thereafter add some comments on the apparent geopolitical visions inspiring the practiced geopolitics of the three most immediate external powers: Russia, the US and the EU.

In late 1991 the Ukrainian leadership was a main contender in the anti-Gorbachev compact that finally secured the dissolution of the USSR. Ukraine became an independent state. Apparently KAISER's model of ethnic nationalism also applied to the Ukraine. But there had always been language differences between West and East Ukraine, also variations in the geographical distribution of groups with a different ethnic status. The regions of Ukraine had been variously involved in industrialisation and urbanisation and in the blood-lands episodes of the 1930s and 1940s (SNYDER, T. 2010). In addition, Ukraine's current territory has a checkered earlier territorial history (JANSEN, M. 2014). Allegiance to a unitary Ukrainian state is more widespread in the West and among the better educated and younger age groups but it is uncertain to what extent this is generally based on strong nationalism. It may just as well result from a preference to be unequivocally part of the West. Karácsonyi et al. provide a detailed overview of the East-West dichotomy in Ukraine (KARÁCSONYI, D. et al. 2014, 99-134). They consider the current East-West political fault line as conditioned by earlier physical, cultural and socio-economic geographical variation. Similar differences can be found in other post communist societies, but in Ukraine they are expressed in unusually strong regional variations. In the end they do not interpret the Ukrainian conflict as an example of the clash of civilizations that Huntington foresaw (Huntington, S. 1993).

In the Maidan protests there was a diversity of views. The initial protesters and always a strong fraction in the subsequent stages were interested in a more open society where the law would be respected, democracy taken seriously, pervasive corruption would be countered and a free entrepreneurial spirit would be encouraged. Nationalism was not an end to pursue, but some form of national unity would be needed to accomplish the real aims. This was the non violent part of the protest. But other fractions were primarily interested in the realisation of the nation in one of its available versions accepting one of its different founding myths. This gave rise to violent forms of protest, armaments and tight organisation in the end leading to the different voluntary batallions that took part in the Ukrainian military campaign. Some of the initial non violent protesters also became part of new Ukrainian batallions opposing the separatists and Russian forces, notably some driven from their homes in separatist held territory who gathered in the Donbass batallion. Efforts have been made to incorporate all of them in the standing army but this has occasionally been resisted for ideological reasons as well as for the meagre facilities that the regular army is able to provide. There have apparently been successes over time but there are also signs of armed resistance by fighters returned from the front line against the Kiev regime. In fact there is a whole variety of subsequent situations, reactions and loyalties with many lives disrupted by traumatic experiences (SchuelleR, K. 2015). 
In their latest survey Toal and O'LoughLin have found levels of allegiance to Ukraine by implication, asking for the attitudes of their respondents to the notion of Novorossiya. Their surveys were held in Crimea and in the six oblasts that together with Lukhansk and Donetsk (too insecure to provide reliable responses at the time) form the region that has by the Russian side been labelled Novorossiya for a while. The results show a very low level of Ukrainian allegiance in Crimea but much higher levels in all the six south-eastern oblasts with a bit more hesitance in Kharkiv and Odessa than elsewhere. Other research from the end of 2013 shows low levels of Ukrainian allegiance in the city of Lukhansk but relatively higher levels among the local young and the better educated (Toal, G. and O'Loughlin, J. 2015).

If any national feeling toward their newly launched republics has been accomplished in those parts of the Donetsk and Lukhansk oblasts that are under rebel control, is an open question. The rebels have never been a completely united force and there have been serious incidents of local chiefs eliminated by others in attempts to gain ground. Other conflicts opposed volunteers arrived from Russia and indigenous leaders. A story written during the early part of the Ukrainian campaign in June 2014 provides an overview (Schueller, K. 2014). Although later on the collection of participants shifted slightly, the story remained essentially the same. There is not much evidence of great popular enthusiasm. The general feeling seems to be more oriented towards an ending of the violence from all sides than anything else and a widespread nostalgia to the stability of Soviet times. The networks of the oligarchs who have controlled major parts of the region for many years are apparently still partly intact.

The practiced geopolitics in the Ukraine case are by no means only those of the Ukrainian contenders. Major roles are played by the EU (also in this case largely but not completely guided by German diplomacy). Its performance as a negotiating party in the association agreement with Ukraine was of central importance in setting the conditions for the conflict formation. The Russian federation actively opposed the agreement, was already deeply involved in Ukrainian politics and then steeply escalated the crisis by taking possession of the Crimea and taking an active part in the armed rebellion in Eastern Ukraine from spring 2014. The US acted as the great power always deemed indispensable by many of its European partners and in the end often ready for activist intervention at least at the diplomatic level and with repeated public references to military options at least by congressional politicians. EU, Russia and US carry dominant geopolitical visions that provide general guidance and in fact show contrary tendencies.

The EU's geopolitical vision for its adjacent zone in the East and the South had been from 2004 the so called European Neighbourhood Policy (ENP). It was inspired by the notion that instead of future membership of the Union it would be better to develop good neighbour relations. The EU would play the benevolent partner helping the neighbours on a trajectory toward more convergence with EU norms. This would create peace and stability across its borders. The Association agreement was the latest step in that direction as regards Ukraine. The current Ukraine conflict ensued. Elsewhere in the zone of the European Neighbourhood Policy the Syrian war and the continuing Libyan crisis after Khadaffi's disappearance show no signs of subsiding. For a long period already the EU is additionally confronted with unmanageable immigration movements arriving through and from its zone of neighbours culminating in the current large scale disaster. The ENP is now being revamped but the problems to overcome are clearly immense (the most recent self report on this re-orientation is http:// eeas.europa.eu/top_stories/2015/300615_enpconsultation_en.htm ).

In the Russian Federation geopolitics has won quite some traction since the demise of the USSR as we saw earlier in de Google based graphs. Now that Russia found itself 
in circumstances comparable to the German position after World War I, it was attractive to follow in Haushofer's footsteps. Geopolitical visions of Russia's fate in the contemporary world based on classical German geopolitics were combined with the indigenous notion of Russia as the unique combination of European and Asian features due to its geographical position developed by geographers and others before the revolution and then mainly continued in the circles of emigrants.

One early protagonist was Alexander Dugin who has been a steady inspiration for others but who has also provoked much resistance (Dugin, A. 1997). Long considered a weird, local voice (he is hardly taken seriously in Trenin, D. [2002], a prominent voice at the time in these matters), he got an international following in more recent years mostly in extreme right circles by his strong advocacy of resistance against Anglo-Saxon capitalism. Knowledgeable observers call him a fascist. Dugin has for many years taken radical positions vis à vis Ukraine re-commending its wholesale incorporation in the Russian federation. Putin has proposed his geopolitical disaster thesis of the USSR since 2005. Particularly after the repossession of the Crimea he has on a few occasions engaged in geopolitical visions inspired by these autocratic Tsarist and Eurasianist notions mixing ethno-national, Orthodox and territorial notions. It is a vision with high risk implications for a peaceful resolution of the Ukraine situation as long as its potential claims for a further occupation of some version of Novorossiya not to speak of the political position of other former parts of the USSR are not put on ice.

It is by no means certain with how much conviction such visions are now put forward by Russia's power holders. For the time being they have aroused considerable popular support. But even their mere announcement creates further problems for Russia's strained economy that does not allow it to perform as a great power for any sustained period of time. In autumn 2015 the emphasis in Russian foreign policy abruptly shifted to Syria and the Middle East. In Ukraine a cease fire, finally, seemed to take hold, apparently facilitated by an enhanced willingness for compromise solutions from the side of various parties, but the situation remains highly volatile.

In US policy-making circles, there are still remnants of the memory of World War II when the geopolitical vision on how to prevail against the German and Japanese threats was developed. In my view, Nicholas SрукмAN's American's Strategy in World Politics. The US and the Balance of Power (SPYKMAN, N. 1942) is a key text on the subject that has unjustly been a bit forgotten despite a reprint in 2007. The book was published just after Pearl Harbour. It reacted to the global situation but also looked beyond the war's end. SPYKMAN stated in no uncertain terms that the US after winning the war under no circumstances should withdraw completely from the Eurasian rimlands and in particular from the industrial concentrations in and around Germany and Japan. It would need to play a permanent role in the balance of power in those areas. This was when the USSR was an ally. In the end the US remained present on the Eastern shores of the Atlantic and the Western shores of the Pacific.

In the West practiced geopolitics subsequently resulted in NATO. As the Cold War receded NATO was retained, and eventually extended across much of Eastern Europe not in the least upon the request of countries that had recently lost the overlordship of the USSR. It was apparently not only this series of requests that rolled NATO forward (seen from the Russian perspective). It was also America's need to affirm that the Cold War had a winner. Russia was given some consulting role in NATO that was clearly insufficient to prevent the souring of relations. The OSCE was instituted as a new all-European platform including the US and Canada but it remained a pretty weak organization.

It could have been otherwise. NATO could have withered away and OSCE developed as the assurance of American presence in Europe. After all, Spyкman's aim had not 
been a bloc, but a balance of power. Such a course could perhaps have altered the calculations on the other side. This is certainly a highly contentious issue across Europe as the relevant assessments will certainly differ between East and West Europe. Under the circumstances the Americans perceive the Ukraine situation largely through a NATO lens while the OSCE, that does the difficult work on the ground, could use more generous backing.

\section{Final remarks}

I close with three notions that I got out of all this:

Nationalism, Benedict ANDERson wrote, was a question of imagined communities and they were the basis for a preference for absolute political autonomy: the nation state. These communities won out over other communities due to the printing press and territorial government. Now, the predominance of printing press and territorial government has in many places subsided, social media and governance has emerged. Perhaps, the dominance of politically relevant nationalism is also somewhat receding, with religiously based, sports based and other commonalities competing fiercely for primary attention and allegiance.

It is globalisation that has transformed the media environment and relativises territorial government and thus undermines the conditions for nationalism. But at the same time globalisation undermines general conditions of existential stability and thereby unleashes attempts to restore the certainties of yesteryear, e.g. the imagined national community. The final outcome of this dual process is highly contingent.

As territorial government becomes enmeshed in a cloud of governance by all kinds of governing arrangements occupied with different kinds of governors and subjects and a nationalist ideology is no longer the self-evident vessel for a geopolitical vision, geopolitical visions may well become more ephemeral and temporary; and their adher- ence may crumble. The transition to more differentiated systems of governance implies a multiplication of geopolitical practices. This may well result in irresolvable knots of competence rivalry that inhibit more or less harmonious social development. Such transitions are, however, actively resisted by authoritarian regimes that suppress diversity and impose simplification thus also harming smooth social functioning. Avoiding these two unsatisfactory states of affairs is the true art of contemporary politics.

\section{REFERENCES}

Anderson, B. 1983. Imagined communities: Reflections on the origin and spread of nationalism. London, Verso.

Anderson, B. 1992. Long-distance nationalism: world capitalism and the rise of identity politics. Wertheim lecture. Amsterdam, CASA.

Connor, W. 1978. A nation is a nation, is a state, is an ethnic group, is a ... Ethnic and Racial Studies 1. 377-400.

Dalby, S. and O'Tuathail, G. (eds.) 1998. Rethinking geopolitics. London, Routledge.

Deutsch, K.W. 1953. Nationalism and social communication. Cambridge, Mass., MIT Press.

DiJKInK, G.J.W. 1996. National Identity and Geopolitical visions: maps of pride and pain. Routledge, London

Dugin, A. 1997. Osnovy geopolitiki: geopoliticheskoe budushchee Rossii (The foundations of geopolitics: the geopolitical future of Russia). Moscow, Arktogeia.

European External Action Service 2015. Revision ENP: http://eeas.europa.eu/top_stories/2015 /300615_enp-consultation_en.htm

Gellner, E. 1983. Nations and nationalism. Ithaca, Cornell University Press.

Haushofer, K., Obst, E., Lautensach, H. and Maull, O. 1928. Bausteine zur Geopolitik. Berlin, Kurt Vowinckel Verlag, Berlin.

Holdar, S. 1994. Lemmas Geopolitik - Origins and Kjellén, Rudolf. In Dictionary of Geopolitics. Ed.: O'Loughlin, J., Westport, Greenwood Press, 93-95, 138-142.

Нroch, M. 1985. Social preconditions of national revival in Europe. Cambridge University Press, Cambridge.

Huntington, S. 1993. The clash of civilizations? Foreign Affairs 72. (3): 22-49.

JAnsen, M. 2014. Grensland. Een geschiedenis van Oekraïne. Amsterdam, Van Oorschot.

KaIser, R.J. 1994. The Geography of Nationalism in Russia and the USSR. Princeton, N.J., Princeton University Press. 
Karácsonyi, D., Kocsis, K., Kovály, K., Molnár, J. and Póti, L. 2014. East-West dichotomy and political conflict in Ukraine - Was Huntington right? Hungarian Geographical Bulletin 63. (2): 99-134.

KJellén, R. 1917. Der Staat als Lebensform. Leipzig, S. Hirzel.

MAckinder, H.J. 1904. The geographical pivot of history. Geographical Journal 23.421-437.

N-gram VIEWER: https://books.google.com/ngrams

O'Loughlin, J., Kolossov, V. and Toal, G. 2011. Inside Abkhazia: Survey of Attitudes in a De Facto State. Post-Soviet Affairs 27. (1): 1-36.

O'Loughlin, J., Toal, G. and Chamberlain-Chenga, R. 2013. Divided Space, Divided Attitudes? A Comparative Analysis of Simultaneous Surveys in the Republics of Moldova and Pridnestrovie (Transnistria). Eurasian Geography and Economics 54. (2): 227-258.

O’Tuathail, G. and Agnew, J. 1992. Geopolitics and discourse: practical geopolitical reasoning and American foreign policy. Political Geography 11. 190-204.

PAasi, A. 1996. Territories, Boundaries and Consciousness. The changing geographies of the Finnish-Russian border. Chichester, John Wiley.

Rотн, J. 1932. Radetzkymarsch. Berlin, Gustav Kiepenheuer Verlag.

Schueller, K. 2014. Mehr Grenzen als Grenzer. Frankfurter Allgemeine Zeitung 11.06.2014 http:// www.faz.net/aktuell/politik/ausland/europa/ostukraine-mehr-grenzen-als-grenzer-1282579. html
Schueller, K. 2015. Der Krieg verändert sie alle. Frankfurter Allgemeine Zeitung 12.09.2015. http://www. faz.net/aktuell/politik/ausland/europa/krieg-in-derukraine-besuch-im-donbass-bataillon-13797806. html?printPagedArticle=true\#pageIndex_2

Sмiтh, A.D. 1986. The ethnic origin of nations. Oxford, Blackwell.

SNyder, T. 2010. Bloodlands. Europe between Hitler and Stalin. New York, Basic Books.

Spyкman, N. 1942. America's Strategy in World Politics. The US and the Balance of Power. New York, Harcourt, Brace \& Co.

Tont, G. and O'Loughlin, J. 2013a. Land for Peace in Nagorny Karabakh? Political Geographies and Public Attitudes Inside a De Facto State. Territory, Politics, Governance 1. (2): 158-182.

Toal, G. and O'Loughlin, J. 2013b. Inside South Ossetia: Survey of Attitudes in a De Facto State. Post-Soviet Affairs 29. (2): 136-172.

ToAl, G. and O'Loughlin, J. 2015. Blogpost Washington Post on S.E. Ukraine, 25 May 2015: https://www. washington post.com/blogs/monkey-cage/ wp/2015/05/25/what-people-in-southeast-ukrainereally-think-of-novorossiya/

Trenin, D. 2002. The end of Eurasia. Russia on the border between Geopolitics and Globalization. Washington - Moscow, Carnegie Endowment for International Peace.

VAn der Wusten, H. 1980. The United Kingdom and its Irish contenders (1800-1922). Netherlands Journal of Sociology 16. 171-184. 


\title{
Minsk and Budapest, the two capital cities
}

\author{
Edited by
}

\author{
LÁsZló Jeney and DÁvid Karácsonyi
}

\begin{abstract}
Department of Economic Geography and Futures Studies, Corvinus University of Budapest; Geographical Institute RCAES HAS; Faculty of Geography, Belarusian State University; Institute for Nature Management, National Academy of Sciences of Belarus
\end{abstract}

Budapest, 2015. 194 p.

While Budapest used to be the bridge between the West and East in Central Europe, Minsk seems to be in a similar role between the Russian and the EU-Polish influence zones. It means that both capitals are situated on the frontiers between the Euro-Atlantic and the Euro-Asian macro regions. Besides their situations, their similarity in size renders the comparison and the cooperation obvious to proceed. This book is based

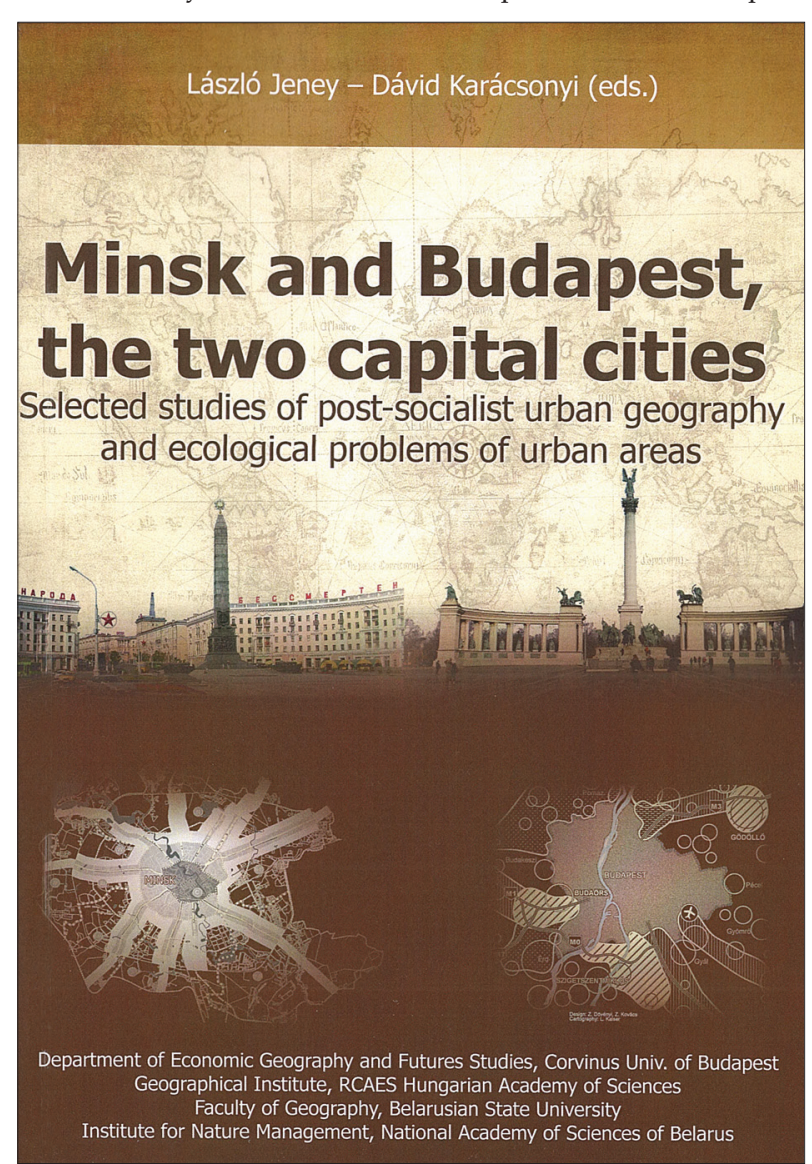

on the mutual co-operation of Hungarian and Belarussian geographers and gives a scientific outlook not only on the socioeconomic development of the two cities but on the urban climate, environment and ecology as well. Hungarian authors of the book introduce Budapest as a Central European metropolis with its historical trajectories and the results of the post-socialist transformation. They also demonstrate the main features of large housing estates and the results of their rehabilitation. Authors from Belarus show the major issues of spatial structure planning of Minsk in a similar context, describing the past and the present changes taking place in the spatial structure of the metropolis. The integrated assessment of the state of urban environment in Minsk is examined also focusing on the ecological frame of the environmental planning in urban agglomerations. The volume serves as a good starting point of a fruitful co-operation between Belarussian and Hungarian geographers dealing with a social and physical urban environment, the state of which deserves extra attention especially in East Central and Eastern Europe.

Copies are available:

Library, Geographical Institute of RCAES HAS, H-1112 Budapest, Budaörsi u. 44.

E-mail: magyar.arpad@csfk.mta.hu 